\title{
Hubungan Pola Asuh Ibu Bekerja dengan Perkembangan Sosial Anak Prasekolah Umur (3-5 Tahun) di Desa Pargarutan Julu Kecamatan Angkola Timur Kabupaten Tapanuli Selatan Tahun 2020
}

\author{
Ummi Irmadani Harahap
}

Program Studi Kebidanan, Akademi Kebidanan Mitra Syuhada Padangsidimpuan

\section{Info Artikel}

\section{Article history:}

Diterima 17-06-2021

Revisi 28-06-2021

Disetujui 22-07-2021

\section{Kata kunci:}

Pola asuh ibu, Prasekolah,

Perkembangan sosial anak.

\begin{abstract}
A B S T R A K
Berkurangnya pola asuh ibu kepada anak akibat orang tua bekerja, hal ini mengakibatkan terbatasnya interaksi orang tua terutama ibu dengan anaknya. Anak kurang mendapat perhatian dari orang tua terutama ibu karena sibuk dengan pekerjaannya, padahal pada usia ini anak sangat membutuhkan perhatian lebih dari ibunya terutama untuk perkembangan sosialnya. Anak yang ibunya tinggal bekerja akan berdampak cenderung manja, kurang bergaul dengan teman-temannya, lebih suka menyendiri, kurang disiplin, kurang mandiri. Biasanya seorang ibu akan merasa bersalah karena meninggalkan anaknya seharian, sehingga ibu akan memenuhi semua permintaan anaknya untuk berbaikan tanpa memikirkan permintaan anaknya baik atau buruk untuk perkembangan anak selanjutnya. Dalam penelitian ini peneliti menggunakan antitatiif dengan pendekatan korelasional atau uji hubungan. Menurut Uhar Suharaputra (2012) penelitian korelasional bertujuan untuk mencari hubungan antara satu variabel dengan variabel lainnya. Lebih lanjut dijelaskan bahwa untuk menentukan tingkat hubungan antar variabel dapat digunakan alat statistik yang disebut koefisien terpilih yaitu yang mengungkapkan perbedaan yang sedang diteliti. Pada penelitian yang bertujuan untuk mengetahui hubungan pola kerja asuh ibu dengan perkembangan sosial anak usia prasekolah (3-5) tahun dapat diketahui bahwa dari 30 responden anak terbanyak adalah perkembangan sosial yang abnormal dengan pola asuh demokratis anak asuh. 7 anak $(53,8)$ dan paling sedikit perkembangan anak abnormal dengan pola asuh permisif sebanyak 2 anak $(15,4 \%)$. Hasil uji ChiSquare diperoleh data nilai Pvalue $=0,001(\mathrm{P}<0,05)$ yang artinya ada hubungan pola asuh ibu bekerja dengan perkembangan sosial anak usia prasekolah usia 3-5 tahun di Desa Pargarutan Julu.
\end{abstract}

\section{Koresponden Penulis:}

Ummi Irmadani Harahap,

Program Studi Keperawatan, Institut Teknologi dan Kesehatan Sumatera Utara,

Jl. Trans Sumatera Bukittinggi - Padang Sidempuan, Sihitang, Padangsidimpuan Tenggara, Kota Padang

Sidempuan, Sumatera Utara 22733.

Email: ummiirmadani@yahoo.com

\section{PENDAHULUAN}

Dalam suatu keluarga anak merupakan harta yang paling berharga sekaligus sebagai pelengkap kebahagiaan dan calon penerus keturunan. Orang tua memegang peran penting dalam merawat, mengasuh, dan membimbing anaknya agar tumbuh kembang anak sesuai dengan perkembangan pada umumnya. Ada dua sifat tumbuh kembang anak yang berbeda, tetapi saling berkaitan dan tidak dapat dipisahkan yaitu pertumbuhan dan perkembangan (Soetjiningsih, 2013).

Pola asuh ibu merupakan salah satu faktor penting dalam menentukan perkembangan sosial pada masa usia prasekolah mempunyai periode emas dimana anak sedang menjalani prose pertumbuhan perkembangan khisusnya perkembangan sosialnya (Wina, 2016). 
Keberadaan orang tua yang keduanya memutuskan untuk bekerja kini sangat lumrah dan tidak di anggap aneh lagi. Namun, hal ini tidak dapat di pungkiri bisa membentuk sebuah perasaan bersalah dalam diri orang tua, karena kedua orang tua bekerja dan harus meninggalkan anaknya. Mereka memang bisa mendapatkan penghasilan lebih untuk memenuhi berbagai kebutuhan.Tetapi di sisi lain kesibukan aktivitas orang tua dapat menimbulkan persoalan, terutama dalam hal pengasuhan anak, karena anak ditinggalkan oleh orang tuanya selama mereka berkerja bisa menyebabkan kurangnya pemenuhan kebutuhan pengasuhan bagi anak (Kamtini, 2015).

Faktor-faktor yang mempengaruhi pola asuh anak :

a. Tingkat pendidikan

Tingkat pendidikan dan pengetahuan orang tua serta pengalamannya sangat berpengaruh dalam mengasuh anak. Orang tua dengan pendidikan tinggi dapat menjadi orang yang berwibawa dalam pola asuh yang diberikan kepada anaknya, sedangkan orang tua yang memanjakan anak lebih banyak memiliki pendidikan sekolah menengah (Kashah, 2014).

b. Lingkungan

Lingkungan banyak mempengaruhi perkembangan anak, maka tidak mustahil jika lingkungan juga ikut serta dalam pola pengasuhan yang diberikan orang tua terhadap anak. Intervensi lebih awal dari orang tua dapat meningkatkan masa depan anak yang lebih baik (Yakhnich, 2016).

c. Budaya

Orang tua mungkin jarang mengikuti cara-cara atau kebiasaan-kebiasaan yang dilakukan oleh masyarakat dalam mengasuh anak (Deki, 2016). Faktor-faktor yang mempengaruhi dalam proses pengasuhan seseorang berasal dari faktor eksternal dan faktor internal. Tidak hanya sesuatu yang ada dalam keluarga, tetapi pengaruh dari luar juga dapat menentukan bagaimana proses pengasuhan seseorang dalam keluarga tersebut berlangsung.

Perkembangan sosial merupakan pencapaian kematangan dalam hubungan sosial. Perkembangan sosial anak sangat dipengaruhi oleh proses bimbingan orang tua terhadap anak dalam berbagai aspek kehidupan sosial, atau norma-norma dalam kehidupan sehari-hari. Dapat juga diartikan sebagai proses belajar untuk menyesuaikan diri terhadap norma-norma dalam kelompok, moral dan tradisi, memperkuat diri menjadi satu kesatuan dan saling berkomunikasi dan bekerja sama. (Susanto, 2013).

Menurut Rusilaanti (2015). Terdapat empat macam pola asuh orang tua yaitu:

1. Pola Asuh Demokratis

Pola asuh demokratis Adalah pola asuh yang memperioritaskan kepentingan anak akan tetapi tidak ragu-ragu mengendalikan mereka. Pola asuh demokatis merupakan sikap pola asuh dimana orang tua memberikan kesempatan kepada anak dalam pendapatnya dengan tetapi orang tua masih mempertimbangkan antara keduanya akan tetapi hasil akhir tetap ditangan orang tua.

2. Pola Asuh Otoriter

Pola asuh otoriter Adalah pola asuh yang merupakan kebalikan dari pola asuh demokratis yaitu cenderung menetapkan standar yang mutlak harus dituruti, biasanya disertai dengan ancamanancaman. Bentuk pola asuh ini menekankan pada pengawasan orang tua atau kontrol yang ditunjukkan pada anak untuk mendapatkan kepatuhan dan ketaatan, akan tetapi cenderung memaksa seorang anak untuk berbuat sesuai yang di inginkan orang tua.

3. Pola Asuh Permisif

Pola asuh permisif adalah bentuk pengasuhan dimana orang tua memberikan kebebasan sebanyak mungkin kepada anak untuk mengatur dirinya, anak tidak dituntut oleh orang tuanya untuk bertanggung jawab dan tidak banyak di kontrol oleh orang tua.

Orang tua tidak menegur atau memperingatkan anak apabila anak sedang dalam bahaya atau salah, dan sangat sedikit bimbingan yang diberikan oleh mereka. Namun, orang tua tipe ini bersifat hangat sehingga sering kali disukai oleh anak. Pola asuh permisif ini yaitu sikap pola asuh orang tua yang cenderung membiarkan dan memberikan kebebasan kepada anak untuk melakukan berbagai hal.

4. Pola Asuh Tipe Penelantar

JURKESMAS : Jurnal Kesehatan Masyarakat, Vol. 1, No. 1, Juli 2021: 81 - 85 
Pola asuh orang tua tipe ini pada umumnya memberikan waktu dan biaya yang sangat minim pada anak-anaknya. Waktu mereka banyak digunakan untuk keperluan pribadi mereka, seperti bekerja, dan juga terkadang biaya pun dihemat-hematkan untuk anak mereka. Pada pola asuh tipe ini adalah penelantar secara fisik dan psikis pada ibu yang depresi, anak yang tidak dalam pengawasan orang tua bahkan tidak ada.

Word Health Organitation (WHO, 2010) melaporkan bahwa 5-25 \%anak-anak usia prasekolah menderita disfungsi otak minor, termasuk gangguan motorik halus. Anak mengalami periode kritis pada usia perkembangan dibawah 5 tahun, berbagai bentuk penyakit, kekurangan gizi, serta kekurangan kasih sayang maupun kekurangan stimulasi pada usia ini akan membawa dampak negatif yang menetap sampai masa dewasa bahkan sampai usia lanjut (Depkes, 2013). Hampir 50\% anak usia 1-3 tahun di 54 negara maju menunjukkan beberapa simptom gangguan perilaku anti sosial yang dapat berkembang menjadi gangguan perilaku tetap di kemudian hari. Fenomena ini terjadi di berbagai negara misalnya di Kanada dan Selandia baru menunjukkan sekitar 5-7\% anak mengalami anti sosial, selain itu akibat dari pola pengasuhan yang salah dari ibu. Sekitar 5 hingga $10 \%$ anak di perkirakan mengalami keterlambatan perkembangan ( Tatik Suryani, 2013). Berdasarkan Kemenkes RI, 2018 bahwa 88,3\% balita dan anak usia pra sekolah mengalami gangguan perkembangan, baik perkembangan literasi, fisik, sosial emosional, kecerdasan kurang dan keterlambatan. Menurut Ikatan Dokter Anak Indonesia (IDAI) Jawa Timur sebesar 53\% anak usia prasekolah mengalami gangguan perkembangan yakni motorik kasar, motorik halus, bahasa dan perkembangan sosial (Wakhida, 2017).

Studi Pendahuluan yang dilakukan peneliti di Desa Pargarutan Julu Kecamatan Angkola Timur Kabupaten Tapanuli Selatan pada bulan juni 2020 lalu, melalui observasi, wawancara dengan kepala Desa, bahwa ditemukan sekitar 17-20\% anak yang masih mengalami keterlambatan perkembangan sosial dan didapatkan bahwa keseluruhan anak di Desa tersebut karena pola asuh ibu. Berdasarkan uraian tersebut, peneliti tertarik untuk melakukan penelitian dengan judul "Hubungan Pola Asuh Ibu Bekerja Dengan Perkembangan Sosial Anak Umur 3-5 tahun Di Desa Pargarutan Julu, Kecamatan Angkola Timur Kabupaten Tapanuli Selatan Tahun 2020.”.

\section{METODE PENELITIAN}

Penelitian ini di mulai dari melakukan penelitian di bulan Juni 2020, kemudian pengambilan data di Desa Pargarutan Julu kecamatan angkola timur kabupatean Tapanuli Selatan Juli 2020. Penelitian ini menggunakan penelitian kuantitatif dengan menggunakan korelasional atau uji hubungan . Instrumen yang digunakan adalah pola asuh ibu dengan perkembangan sosial anak umur 3-5 tahun di Desa Pargarutan Julu . Sampel Penelitian sebanyak 30 responden, dengan tekhnik pengambilan sampel purposive sampling. Penelitian ini menggunakan analisis univariat dan bivariat untuk mendeskripsikan karakteristik masing-masing variabel yang di teliti. Analisa data menggunakan uji Chi Square.

\section{HASIL DAN PEMBAHASAN}

\section{a. Kararakteristik Responden}

Tabel 1. Karakteristik Responden Distribusi Berdasarkan Umur

\begin{tabular}{lll}
\hline Umur & Frekuensi & Persentase \\
3 TAHUN & 10 & 33.3 \\
4 TAHUN & 11 & 36.7 \\
5 TAHUN & 9 & 30.0 \\
Total & 30 & 100.0 \\
\hline
\end{tabular}

Bedasarkan data karakteristik responden berdasarkaan umur anak yang memiliki anak umur 3 tahun adalah sebanyak 10 orang $(33,33 \%)$, anak berumur 4 tahun 11 orang $(36,7 \%)$, sedangkan yang berumur 5 tahun 9 orang $(30,0 \%)$.

Tabel 2. Karakteristik Responden Berdasarkan Jenis Kelamin

\begin{tabular}{lcc}
\hline Jenis kelamin & Frekuensi & Persentase \\
Laki-laki & 14 & 46.7 \\
Perempuan & 16 & 53.3 \\
Total & 30 & 100.0
\end{tabular}


Berdasarkan data karakteristik responden untuk ibu bekerja yang memiliki anak, yang berjenis kelamin adalah perempuan 16 orang $(53,3 \%)$ dan yang berjenis kelamin laki-laki 14 orang $(46,7 \%)$.

Tabel 3. Karakteristik Umur Ibu

\begin{tabular}{lcc}
\hline Umur & Frekuensi & Persentase \\
30-35 TAHUN & 20 & 66.7 \\
40 TAHUN & 10 & 33.3 \\
\hline
\end{tabular}

Berdasarkan data karakteristik responden berdasarkan umur ibu 30-35 tahun sebanyak 20 orang $(66,7 \%)$, dan ibu yang berumur 40 tahun 10 oarang $(33, \%)$.

\begin{tabular}{lcc} 
Tabel 4. Karakteristik Responden & Berdasarkan Pekerjaan \\
\hline Pekerjaan & Frekuensi & Persentase \\
Wirausaha & 8 & 26.7 \\
Honorer & 11 & 36.7 \\
Pns & 11 & 36.7 \\
Total & 30 & 100.0 \\
\hline
\end{tabular}

Berdasarkan data karakteristik pekerjaan ibu sebagai PNS 11 orang (36.7\%) pekerjaan ibu sebagai Honore 11 orang (36.7\%) pekerjaan ibu sebagai wirausha 8 orang $(26.7 \%)$.

\section{b. Analisis Univariat}

Tabel 5. Karakteristik Responden Berdasarkan perkembangan sosial

\begin{tabular}{lcc}
\hline Perkembangan sosial & Frekuensi & Presentase \\
Normal & 17 & 56.7 \\
Abnormal & 13 & 43.3 \\
Total & 30 & 100.0
\end{tabular}

Berdasarkan karakteristik responden perkembangan sosial anak normal 17 anak (56.7) dan perkembangan sosial anak abnormal 13 anak (43.3\%).

Tabel 6. Karakteristik Responden Berdasarkan Pola Asuh Ibu

\begin{tabular}{lcc}
\hline Pola asuh & Frekuensi & Pesentase \\
Demokratis & 10 & 33.3 \\
Otoriter & 9 & 30.0 \\
Permisif & 7 & 23.3 \\
Penelantar & 4 & 13.3 \\
Total & 30 & 100.0 \\
\hline
\end{tabular}

Karakteristik responden berdasarkan pola asuh ibu demokratis $10 \mathrm{ibu}(33.3 \%)$, pola asuh ibu otoriter $9 \mathrm{ibu}$ (30.0), pola asuh ibu permisif $7 \mathrm{ibu}(23.3 \%)$ dan pola asuh ibu penelantar $4 \mathrm{ibu}(13.3 \%)$.

\section{c. Hasil Analisis Bivariat}

\begin{tabular}{llllllll}
\hline PERKEMBANG & POLA & & & & & & \\
AN SOSIAL & ASUH & & & & & \\
& DEMOKRA & OTORITE & PERMISI & PENELAN & TOT & P- \\
& TIS & R & F & TAR & AL & \\
& F & F & F & F & & \\
NORMAL & $3(17.6 \%)$ & $5(29.4 \%)$ & $5(29.4 \%)$ & $4(23.5 \%)$ & 17 & 0.01 \\
ABNORMAL & $7(53.8 \%)$ & $4(30.8 \%)$ & $2(15.4 \%)$ & $0(0.0 \%)$ & 13 & \\
\hline
\end{tabular}

Analisis bivariat digunakan untuk mengetahui hubungan variabel independen yaitu Pola asuh ibu bekerja dengan variabel dependen perkembangan sosial pada anak dengan menggubkan uji chisquare dengan tingkat keperjayaan $(\alpha=0,05)$.

Berdasarkan tabel dapat diketauhi bahwa dari 30 responden anak yang paling banyak yaitu perkembangan sosial abnormal dengan pola asuh demokratis 7 anak $(53,8)$ dan paling sedikit yaitu perkembangan anak abnormal dengan pola asuh permisif 2 anak (15.4\%). Hasil uji chi-Square di peroleh data nilai Pvalue $=0,001(\mathrm{P}<0,05)$ yang artinya ada hubungan pola asuh ibu bekerja dengan perkembangan sosial anak pra sekolah umur 3-5 tahun di Desa Pargarutan Julu.

Berdasarkan hasil penelitian yang telah dilakukan di Desa Pargarutan Julu dapat diketahui bahwa dari 30 responden untuk ibu bekerja yang memiliki pola asuh Demokratis 10 ibu 
(33.3\%). Berdasarkan hasil penelitian yang telah dilakukan di Desa Pargarutan Julu dapat diketahui bahwa dari 30 responden untuk ibu bekerja yang memiliki pola asuh ibu otoriter 9 anak (30.0\%), Berdasarkan hasil penelitian yang telah dilakukan di Desa Pargarutan Julu dapat diketahui bahwa dari 30 responden untuk ibu bekerja yang memiliki Pola asuh Permisif 7 anak $(23,3 \%)$. Berdasarkan hasil penelitian yang telah dilakukan di Desa Pargarutan Julu dapat diketahui bahwa dari 30 responden untuk ibu bekerja yang memiliki pola asuh tipe penelantar 4 anak (13,3\%). Jadi berdasarkan tabel dapat diketahui bahwa ibu bekerja yang memiliki anak prasekolah umur 3-5 tahun di Desa Pargarutan Julu, lebih banyak pola asuh demokratis yaitu jumlah 10 anak (33.3\%). Anak di beri kebebasan yang bertanggung jawab, artinya apa yang dilakukan oleh anak harus tetap dibawah pengawasan orang tua.

\section{KESIMPULAN}

Berdasarkan hasil penelitian yang te;ah dilakukan di Desa Pargarutan Julu tahun 2020, tentang pola asuh ibu bekerja dengan perkembangan sosial anak usia pra sekolah umur 3-5 tahun, frekuensi terbanyak adalah pola asuh ibu bekerja dengan kategori pola asuh demokratis yaitu jumlah 10 anak (33,3\%). Minoritas pola asuh ibu bekerja yang memiliki pola asuh tipe penelantar 4 anak $(13,3 \%)$.

\section{REFERENSI}

Deki, 2016. Factor Affecting Early Chidhood Growth and Development: Golden 100 Days. Advanced Practices In Nursing.

Kamtini, Motorik Kasar Anak Usia Dini, Medan: Media Perdana, 2014.

Rusilaanti. 2015. Gizi dan Kesehatan Anak Prasekolah. Bandung : PT Remaja Rosdakarya.

Soetjingsih \&Ranuh, G. (2013). Tumbuh kembang anak. Edisi 2. Jakarta : EGC.

Susanto, Ahmad. 2013. Teori Belajar dan Pembelajaran Disekolah Dasar. (Jakarta: Kencana Prenada Media Group).

Tatik Suryani, 2013, Perilaku Konsumen Di Era Internet, Graha Ilmu, Yogyakarta.

Yaknich, L. (2016). Parntal Experience of Former Soviet Union Immigrant Parents in Israel. Internasional Journal of Child, Youth and Family Studies (2016). 